\title{
Public health impacts of secondary particulate formation from aromatic hydrocarbons in gasoline
}

Katherine von Stackelberg ${ }^{1 *+}$, Jonathan Buonocore ${ }^{1+}$, Prakash V Bhave ${ }^{2}$ and Joel A Schwartz ${ }^{1}$

\begin{abstract}
Background: Aromatic hydrocarbons emitted from gasoline-powered vehicles contribute to the formation of secondary organic aerosol (SOA), which increases the atmospheric mass concentration of fine particles $\left(\mathrm{PM}_{2.5}\right)$. Here we estimate the public health burden associated with exposures to the subset of $\mathrm{PM}_{2.5}$ that originates from vehicle emissions of aromatics under business as usual conditions.

Methods: The $\mathrm{PM}_{2.5}$ contribution from gasoline aromatics is estimated using the Community Multiscale Air Quality (CMAQ) modeling system and the results are compared to ambient measurements from the literature. Marginal $\mathrm{PM}_{2.5}$ annualized concentration changes are used to calculate premature mortalities using concentration-response functions, with a value of mortality reduction approach used to monetize the social cost of mortality impacts. Morbidity impacts are qualitatively discussed.

Results: Modeled aromatic SOA concentrations from CMAQ fall short of ambient measurements by approximately a factor of two nationwide, with strong regional differences. After accounting for this model bias, the estimated public health impacts from exposure to $\mathrm{PM}_{2.5}$ originating from aromatic hydrocarbons in gasoline lead to a central estimate of approximately 3800 predicted premature mortalities nationwide, with estimates ranging from 1800 to over 4700 depending on the specific concentration-response function used. These impacts are associated with total social costs of $\$ 28.2 \mathrm{~B}$, and range from $\$ 13.6 \mathrm{~B}$ to $\$ 34.9 \mathrm{~B}$ in $2006 \$$.

Conclusions: These preliminary quantitative estimates indicate particulates from vehicular emissions of aromatic hydrocarbons demonstrate a nontrivial public health burden. The results provide a baseline from which to evaluate potential public health impacts of changes in gasoline composition.
\end{abstract}

Keywords: Aromatic hydrocarbons, Secondary organic aerosol (SOA), Secondary particulate, Social cost, Gasoline

\section{Background}

Field studies suggest $10 \%-60 \%$ of fine particulate matter $\left(\mathrm{PM}_{2.5}\right)$ is comprised of organic compounds [1-3]. This material may be directly emitted to the atmosphere (primary) or formed from the gas-phase oxidation of hydrocarbon molecules and subsequent absorption into the condensed phase (secondary). The latter portion, referred to as secondary organic aerosol (SOA), is a major contributor to the $\mathrm{PM}_{2.5}$ burden in both urban and rural atmospheres [4-8], which contributes to a range of

\footnotetext{
* Correspondence: kvon@hsph.harvard.edu

${ }^{\dagger}$ Equal contributors

'Harvard Center for Risk Analysis, 401 Park Drive, Landmark 404J, Boston, MA 02215, USA

Full list of author information is available at the end of the article
}

adverse health effects [9-12], visibility reduction [13,14], and global climate change [15-17].

In the atmosphere, SOA can originate from both anthropogenic (e.g., solvent use, mobile sources) and biogenic (e.g., forests) sources. Of the anthropogenic precursors, conventional wisdom is that aromatic hydrocarbons are among the most efficient at forming SOA $[18,19]$. Table 1 lists several empirical studies that estimated the contribution of SOA precursors to observed $\mathrm{PM}_{2.5}$ concentrations. These studies show that aromatics typically contribute between 0.1 to $0.45 \mu \mathrm{g} / \mathrm{m}^{3}$ to observed $\mathrm{PM}_{2.5}$ concentrations [20-23].

A series of sunlight-irradiated, smog-chamber experiments conducted in the 1980's suggested that the

\section{Biomed Central}


Table 1 Studies evaluating the contribution of aromatic hydrocarbons to SOA

\begin{tabular}{|c|c|c|c|}
\hline Reference & Description & Source apportionment & Concentrations $\left(\mu \mathrm{g} / \mathrm{m}^{3}\right)$ \\
\hline [20] & $\begin{array}{l}\text { Contribution of primary and secondary sources of } \mathrm{OC} \text { to } \mathrm{PM}_{2.5} \text { in } \\
\text { a small subset of Southeastern Aerosol Research and } \\
\text { Characterization (SEARCH) network samples }\end{array}$ & $\begin{array}{l}\text { (2,3-hydroxy-4-oxopentanoic acid used } \\
\text { as a chemical tracer for aromatic SOA }\end{array}$ & $\begin{array}{l}0.10 \text { to } 0.45 \text { across } 4 \text { sampling } \\
\text { locations }\end{array}$ \\
\hline [21] & $\begin{array}{l}\text { Contribution of primary and secondary sources of OC to } \mathrm{PM}_{2.5} \text { in } \\
\text { five midwestern United States cities year-round: East St. Louis, IL } \\
\text { Detroit, MI Cincinnati, OH Bondville, IL and Northbrook, IL }\end{array}$ & $\begin{array}{l}\text { 2,3-hydroxy-4-oxopentanoic acid used } \\
\text { as a chemical tracer for aromatic SOA }\end{array}$ & $\begin{array}{l}\text { Bondville: } 0.09-0.25 \\
\text { Northbrook: } 0.06-0.21 \\
\text { Cincinnati: } 0.02-0.29 \\
\text { Detroit: } 0.07-0.33 \\
\text { East St. Louis: } 0.06-0.26\end{array}$ \\
\hline [22] & $\begin{array}{l}\text { Contribution of primary and secondary sources of OC to } \mathrm{PM}_{2.5} \text { in } \\
2006 \text { in Research Triangle Park, NC over the course of a year }\end{array}$ & $\begin{array}{l}\text { 2,3-hydroxy-4-oxopentanoic acid used } \\
\text { as a chemical tracer for aromatic SOA }\end{array}$ & $\begin{array}{l}\text { average }=0.1, \text { stdev }=0.09 \\
\min =0.02, \max =0.36, n=33\end{array}$ \\
\hline [33] & $\begin{array}{l}\text { Positive matrix factorization of organic marker measurements to } \\
\text { estimate primary and secondary components of organic aerosol }\end{array}$ & $\begin{array}{l}\text { SOA from motor vehicles contribute } \\
11 \% \text { of total organic aerosols }\end{array}$ & method is not quantitative \\
\hline [23] & $\begin{array}{l}\text { Contribution of primary and secondary sources of OC to } \mathrm{PM}_{2.5} \\
\text { in July-August } 2007 \text { in Cleveland, OH, Detroit, } \mathrm{Ml} \text { and LA, CA }\end{array}$ & $\begin{array}{l}\text { 2,3-hydroxy-4-oxopentanoic acid used } \\
\text { as a chemical marker for aromatic } \\
\text { SOA, using a different analytical } \\
\text { method than [20-22] }\end{array}$ & $\begin{array}{l}0.05-1.1 \text { in the midwest; } \\
0.95-1.61 \text { in } C A\end{array}$ \\
\hline
\end{tabular}

$\mathrm{PM}_{2.5}$ formation potential of whole gasoline vapor can be accounted for solely in terms of the aromatic fraction of the fuel [18]. More recent chamber studies show that SOA yields measured under NOx-limited conditions greatly exceed formation under $\mathrm{NOx}$-rich conditions, and that SOA yields under NOx-rich conditions are even greater than were observed previously [24]. Evidence is growing that aromatics in gasoline exhaust are among the most efficient secondary organic matter precursors $[19,25]$. While the relative abundance of primary and secondary organic matter is the subject of ongoing debate [26], air quality models are continually updated to keep up with the latest scientific knowledge [27,28].

In the United States, gasoline-powered vehicles are the largest source of aromatic hydrocarbons to the atmosphere [29]. Most gasoline formulations consist of approximately $20 \%$ aromatic hydrocarbons [30], which are used in place of lead to boost octane. Therefore, it has been suggested that removal of aromatics could reduce SOA concentrations and yield a substantial public health benefit [31]. The issue is complicated by the fact that any change to fuel composition will affect vehicular emissions of various pollutants (e.g., hydrocarbons, carbon monoxide, oxides of nitrogen [NOx], primary $\mathrm{PM}_{2.5}$ ) which, in turn, will react in the atmosphere to produce a different mix of pollutants that may have adverse effects (e.g., [32]). However, a number of studies have noted that gas-phase vehicle emissions lead to a substantial fraction of observed SOA [33]. For example, a source apportionment study of SOA formation during a severe photochemical smog event in Los Angeles found that gasoline engines represented the singlelargest anthropogenic source of SOA [34].
The purpose of this study is to estimate the public health impacts and social costs associated with exposure to SOA from vehicular emissions of aromatic hydrocarbons. This analysis provides a baseline case to explore the magnitude of the issue and against which to evaluate the cost and impacts of potential substitutes for aromatics. The next section describes the methods for the analysis, followed by results and a concluding discussion.

\section{Methods}

Predicted secondary $\mathrm{PM}_{2.5}$ concentrations attributable to single-ringed aromatic hydrocarbons are estimated for a baseline year (2006) using the Community Multiscale Air Quality model version 5.0 (CMAQv5.0). Given that air quality models are known to underestimate anthropogenic SOA formation [19,26,35], our results are compared to available data to estimate scaling factors for adjusting the model results. Adjusted $\mathrm{PM}_{2.5}$ concentrations are then used in the US EPA Benefits and Mapping Program v4.0 (BenMAP) model to estimate morbidity health and mortality outcomes associated with exposure to these concentrations across the lower 48 states [36].

\section{Exposure concentrations}

The CMAQ model is among the most widely used air quality models, with 3000+ registered users in 100 different countries (www.cmaq-model.org). Federal and State regulatory agencies use CMAQ for policy analyses and for routine air quality forecasting [37]. The model provides a means for quantitatively evaluating the impact of air quality management policies prior to implementation. This analysis relied on CMAQv5.0 with the Carbon Bond 2005 (CB05) chemical mechanism, which 
includes a fairly comprehensive list of precursors that lead to SOA formation via both gas- and aqueousphase oxidation processes, as well as particle-phase reactions [27].

Air quality model simulations based on CMAQv5.0 are used to estimate the total concentration of SOA from all single-ring aromatic compounds (e.g., benzene, toluene, xylenes) in uniform $12 \mathrm{~km}$ grid cells across the lower 48 states for a baseline year (2006).

\section{Potential underestimates in predictions of SOA formation}

Although CMAQv5.0 contains updated algorithms and processes for predicting SOA formation, evidence suggests that the model may still underestimate secondary $\mathrm{PM}_{2.5}$ concentrations $[27,28,38]$, particularly during the summer [37]. Experiments conducted at Carnegie Mellon University to study SOA formation from the photooxidation of toluene suggest significantly larger SOA production than parameterizations employed in current air-quality models [39].

Using an organic tracer-based source apportionment approach, independently conducted research over the last five years provides increasing evidence that aromatic hydrocarbons in gasoline contribute, depending on the specific region, approximately 0.1 to $0.45 \mu \mathrm{g} / \mathrm{m}^{3}$ of $\mathrm{PM}$ [20-23].

Given our objective to estimate the public health impact of aromatic SOA, CMAQv5.0 model results must be adjusted to reflect any biases specific to this $\mathrm{PM}_{2.5}$ component. Monthly-averaged model results are compared against empirical estimates of aromatic SOA concentrations derived from ambient measurements of 2,3-dihydroxy-4-oxopentanoic acid collected at twelve locations across the U.S. ([20-23,40]. We develop region-specific regression relationships between modeled CMAQ values and measured concentrations in $\mu \mathrm{g}$ of carbon per $\mathrm{m}^{3}$ and use these to adjust the model results prior to estimating health effects. Regions are based on standard US census designations consistent with the census designations in subsequent linked models (http://www.eia.gov/emeu/mecs/mecs2002/census.

html). We develop a mixed model with a random slope for each region, as there is some indication that slopes should vary by region. For example, Hildebrandt et al. [39] report elevated SOA yields from toluene under high UV intensity, low- $\mathrm{NO}_{\mathrm{x}}$ conditions, and lower temperatures, relative to the parameters used typically in models. Therefore, the slope might be low in California where there is a lot of $\mathrm{NO}_{\mathrm{x}}$ and high in the Midwest and East where ambient temperatures remain relatively low. The overall fixed effect and region-specific random effects models are developed using REML in $R$
Table 2 Regression relationships developed by region to adjust CMAQv5.0 results based on data in Additional file 1: Table S1

\begin{tabular}{lcrrr}
\hline & Value & Standard error & T-value & P-value \\
\hline \multicolumn{2}{l}{ Overall estimate } \\
Intercept & 0.01875 & & & \\
CMAQv5.0 & 1.896 & 0.16 & -0.69 & 0.49 \\
C slope & 2.34 & 1.99 & 0.05
\end{tabular}

Random effects by region

$\begin{array}{lrr}\text { Region } & \text { Intercept } & \text { CMAQv5.0 } \\ \text { Midwest/East } & 0 & 1.12 \\ \text { South } & 0 & -0.269 \\ \text { West } & 0 & -0.856\end{array}$

Final equations used to adjust original CMAQv5.0 results

Midwest/East $\quad$ SOA $=0.01875+3.016^{*} \mathrm{CMAQv} 5.0$

South $\quad$ SOA $=0.01875+1.627^{*} \mathrm{CMAQv} 5.0$

West $\quad \mathrm{SOA}=0.01875+1.04^{*} \mathrm{CMAQv} 5.0$

Model based on Equation 1.

Linear mixed model fit by REML.

Formula: SOA CMAQv5.0 + (CMAQv5.0 | region).

(http://www.r-project.org/) based on the following equation:

$$
\begin{aligned}
\text { Formula: } & \text { SOA CMAQv5.0 } \\
& +(C M A Q v 5.0 \mid \text { region })
\end{aligned}
$$

SOA formation from aromatic hydrocarbons in gasoline SPECIATE, a US EPA database, includes a large repository of volatile organic compound (VOC) speciation profiles of air pollution emission sources [29]. We use these source profiles in conjunction with the National Emissions Inventory (from the year 2005) for VOCs to estimate the nationwide proportion of aromatic VOCs attributable to emissions from gasoline vehicles. We rank order all sources of aromatic VOCs to quantify the contribution to total emissions specifically from gasoline-based sources.

Table 3 National emissions inventory of single-ring aromatic hydrocarbons

\begin{tabular}{lrr}
\hline Source & Aromatic VOC (ton/yr) & \% of total \\
\hline Gasoline & $\mathbf{2 , 4 9 1 , 3 1 3}$ & $\mathbf{6 9 \%}$ \\
Solvent usage & 518,334 & $14 \%$ \\
Diesel & 25,436 & $1 \%$ \\
Other & 573,679 & $16 \%$ \\
Total & $3,608,762$ & $100 \%$ \\
\hline
\end{tabular}

Note:

This information was obtained by combining VOC emissions from the 2005 National Emissions Inventory with speciation profiles from the SPECIATE database. See Additional file 2: Table S2. 


\section{Health and mortality impacts}

The BenMAP model was used to estimate resulting health impacts associated with exposures to the change in $\mathrm{PM}_{2.5}$ concentrations attributable to aromatic hydrocarbons from gasoline vehicles modeled by the process described above. The BenMAP model is widely used by regulatory agencies to quantify and monetize potential health impacts associated with changes in air quality, and contains concentration-response functions for various pollutants, including $\mathrm{PM}_{2.5}$, census data and population projections, and baseline mortality and morbidity rates for the lower 48 United States. Concentration response functions incorporated in BenMAP are based on published studies incorporating different assumptions regarding potential thresholds and observed slopes between concentrations and responses.

Four studies are included in this analysis [12,41-43]. Two major cohort studies are generally thought to provide estimates regarded as most robust and applicable to the general population, with the Harvard Six Cities Study publications reporting central estimates of an approximate $1.2-1.6 \%$ increase in all-cause mortality per $\mu \mathrm{g} / \mathrm{m}^{3}$ increase in annual average $\mathrm{PM}_{2.5}$ [42] and the American Cancer Society studies reporting estimates of approximately $0.4-0.6 \%$ [12], with higher estimates when exposure characterization was more spatially refined [41]. Within the expert elicitation study [43] (Industrial Economics, Inc. 2006) the median concentration-response function across experts was approximately $1 \%$, midway between these cohort estimates, with a median $5^{\text {th }}$ percentile of $0.3 \%$ and a median $95^{\text {th }}$ percentile of $2.0 \%$. The EPA Science Advisory Board external Advisory Committee on Clean Air Act Compliance Analysis recommended developing a distribution with the Pope and Laden studies at the $25^{\text {th }}$ and $75^{\text {th }}$ percentiles, respectively, leading to a mean of the new distribution close to the mean of the central estimates of both Pope and Laden. This generally will be consistent with the distribution identified in the expert elicitation, as recommended by EPA's Science Advisory Board [44]. BenMAP applies these functions to the baseline mortality rate and the number of people potentially exposed by census tract. BenMAP provides distributions of premature mortality estimates based on the uncertainty in the concentration-response functions. That is, the $5^{\text {th }}$ and $95^{\text {th }}$ percentiles in the results are based on the distributions for concentration-response functions only.

\section{Monetized estimates of premature mortality}

Monetized estimates of premature mortality are based on regulatory estimates of the value of mortality risk as defined by the U.S. EPA [45]. This estimate is based on research in which people are asked how much they would pay for consumer products (such as water filters) that reduce risk or alternatively, that examine how much more employers have to pay employees (adjusting for

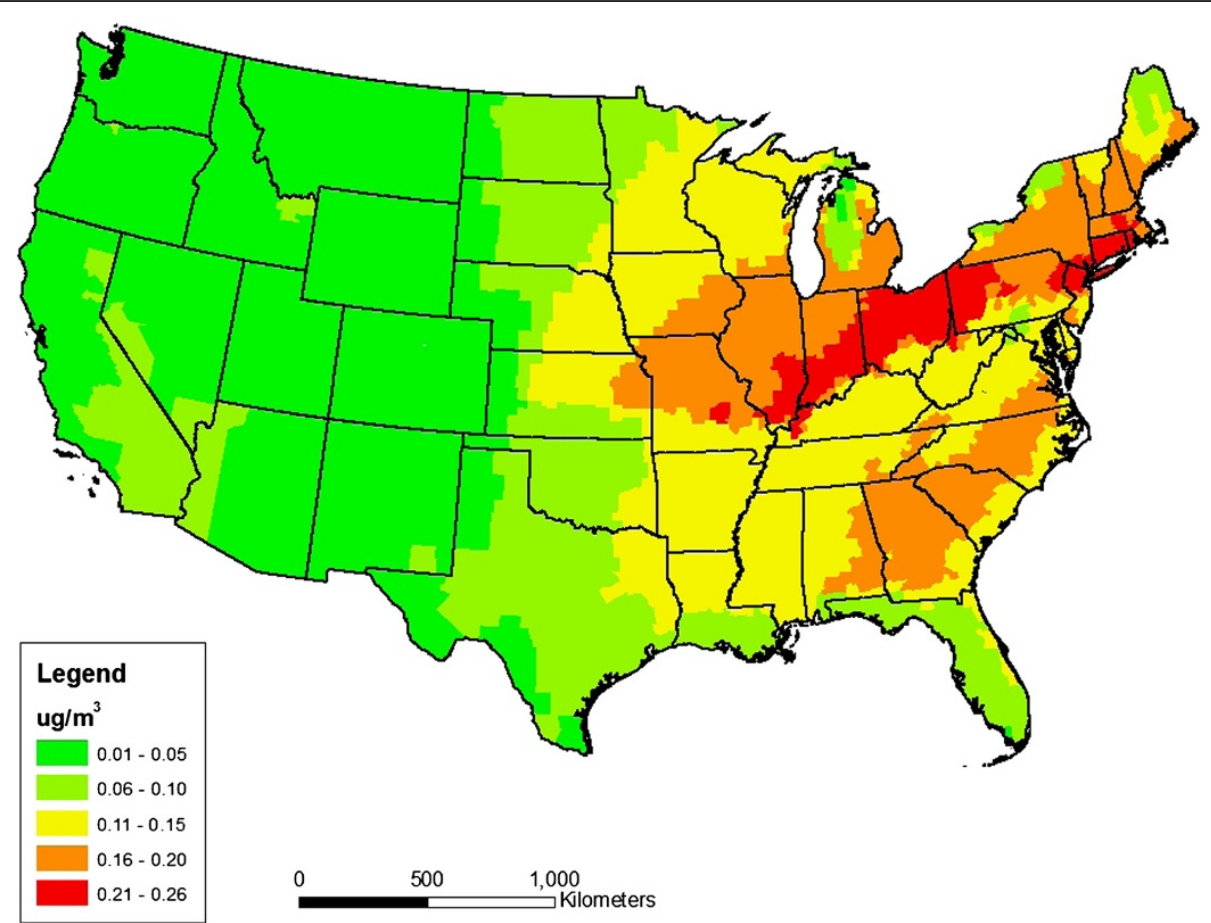

Figure 1 Annual average $\mathrm{PM}_{2.5}$ concentrations attributed to aromatic emissions from gasoline vehicles, after accounting for regionspecific CMAQ model biases and subtracting aromatic contributions from other VOC sources. 
Table 4 State-wide annual average estimates of $\mathrm{PM}_{2.5}$ attributed to aromatic SOA from gasoline emissions

\begin{tabular}{|c|c|}
\hline State & Predicted $\mathrm{PM}_{2.5}$ concentration $\left(\mu \mathrm{g} / \mathrm{m}^{3}\right)$ \\
\hline$\overline{C T}$ & 0.23 \\
\hline Rl & 0.23 \\
\hline $\mathrm{OH}$ & 0.21 \\
\hline NY & 0.21 \\
\hline NJ & 0.20 \\
\hline IN & 0.20 \\
\hline MA & 0.19 \\
\hline $\mathrm{NH}$ & 0.18 \\
\hline IL & 0.17 \\
\hline PA & 0.17 \\
\hline MO & 0.17 \\
\hline Ml & 0.16 \\
\hline SC & 0.16 \\
\hline NC & 0.16 \\
\hline GA & 0.16 \\
\hline VT & 0.15 \\
\hline IA & 0.15 \\
\hline Wl & 0.15 \\
\hline ME & 0.14 \\
\hline KY & 0.14 \\
\hline DE & 0.14 \\
\hline TN & 0.14 \\
\hline$A L$ & 0.14 \\
\hline WV & 0.13 \\
\hline VA & 0.13 \\
\hline MS & 0.13 \\
\hline KS & 0.12 \\
\hline DC & 0.12 \\
\hline MD & 0.12 \\
\hline$A R$ & 0.11 \\
\hline MN & 0.11 \\
\hline NE & 0.11 \\
\hline OK & 0.09 \\
\hline LA & 0.09 \\
\hline SD & 0.09 \\
\hline TX & 0.08 \\
\hline ND & 0.08 \\
\hline $\mathrm{FL}$ & 0.08 \\
\hline NV & 0.05 \\
\hline$A Z$ & 0.05 \\
\hline CA & 0.04 \\
\hline ID & 0.04 \\
\hline MT & 0.03 \\
\hline
\end{tabular}

Table 4 State-wide annual average estimates of $\mathrm{PM}_{2.5}$ attributed to aromatic SOA from gasoline emissions (Continued)

\begin{tabular}{ll}
\hline UT & 0.03 \\
WY & 0.03 \\
OR & 0.03 \\
WA & 0.03 \\
NM & 0.03 \\
CO & 0.03 \\
\hline
\end{tabular}

age, education, experience, etc.) to compensate for taking an increased risk of accidental death. Hence this estimate is not a price on a life, but a price of risk reduction. For convenience it is converted into what was referred to as a value of a statistical life and is now referred to as the value of mortality risk. The implication is if people are willing to pay $\$ \mathrm{X}$ for a reduction in risk of 1 in 10,000, than reducing risk in enough people to produce, on average, one fewer death would be worth 10,000 X dollars. The U.S. EPA recommends a value of $\$ 7.4 \mathrm{M}$ in 2006 dollars [45] based on over 30 labor market and contingent valuation studies.

\section{Results}

CMAQv5.0 modeling results compared to measurements

Additional file 1: Table S1 compiles measurement-based estimates of aromatic SOA collected at twelve locations between 2004 and 2010. Concentrations reach as high as $0.41 \mu \mathrm{gC} / \mathrm{m}^{3}$ during the summer in Cincinnati, with a median value of $0.14 \mu \mathrm{gC} / \mathrm{m}^{3}$ across all 77 samples. In contrast, the CMAQv5.0 model results from the corresponding $12 \mathrm{~km}$ grid cells and averaged over the appropriate month in 2006 show a maximum value of 0.13 and a median of $0.052 \mu \mathrm{gC} / \mathrm{m}^{3}$ (see Additional file 1: Table S1). This systematic bias in the model results warrants some adjustment of the CMAQv5.0 output before it is used in the BenMAP calculations. The mixed model obtained by regressing observations against the CMAQv5.0 results are shown in Table 2. The slopes do differ by region, with the highest slopes observed in the East and Midwest. Aggregated up to the national level, unadjusted CMAQ results predict a nationwide average concentration of $0.045 \mu \mathrm{g} / \mathrm{m}^{3}$, which increases to 0.17 following the adjustment, a factor of approximately 3.8 .

\section{Predicted $\mathrm{PM}_{2.5}$ concentrations from aromatic} hydrocarbons in gasoline

Source-specific speciation of total VOC in the 2005 National Emissions Inventory reveals that the U.S. emissions of single-ring aromatic hydrocarbons are 3.6 million tons per year, of which $69 \%$ are from gasolinepowered vehicles [29] as shown in Table 3. A source-by -source breakdown of all aromatic hydrocarbon emissions 


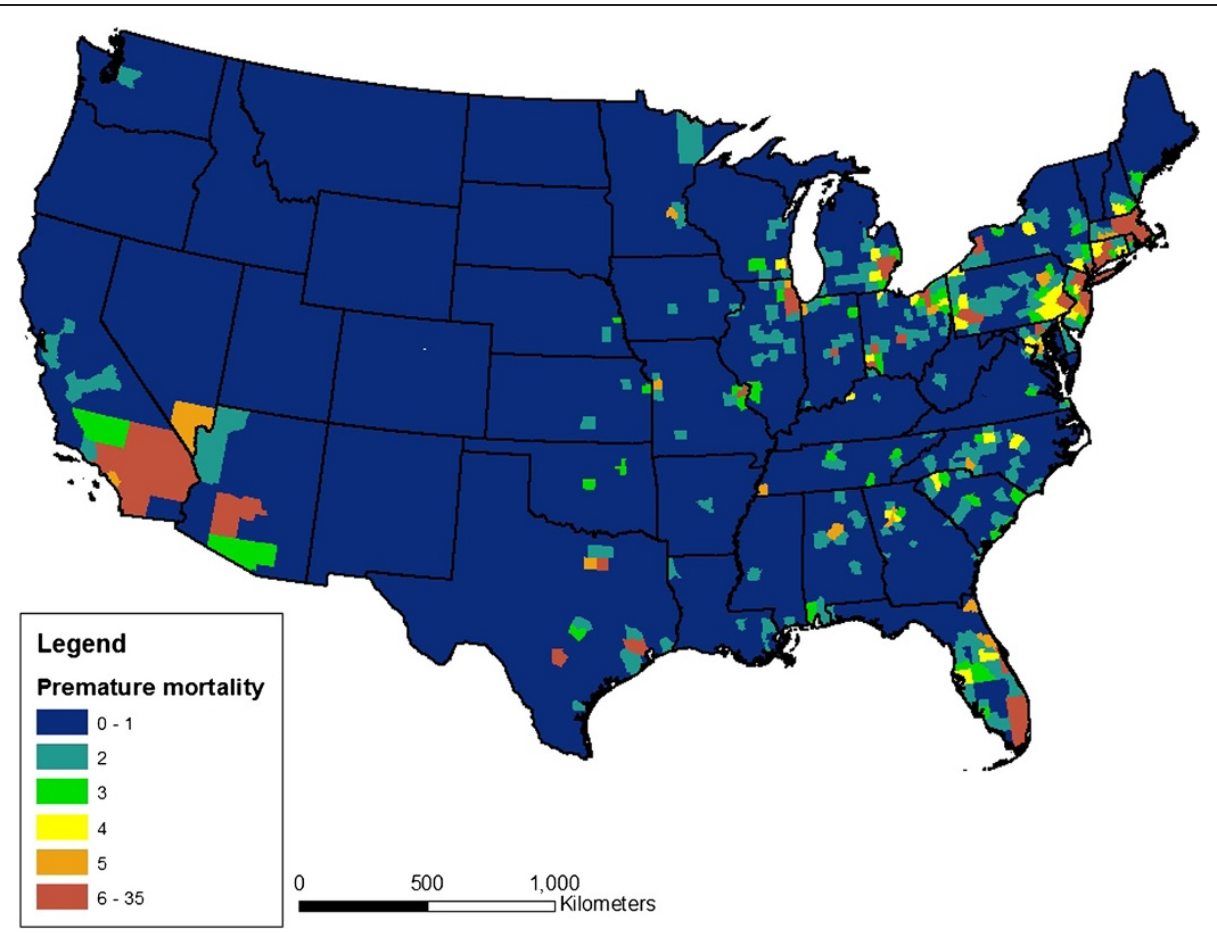

Figure 2 Estimated cases of premature mortality per year in each U.S. county based on the consensus expert elicitation concentration-response function.

is provided in Additional file 2: Table S2. To subtract the contribution of other emission sources (e.g., solvent usage, diesel exhaust) from our calculations, the adjusted aromatic SOA concentrations from CMAQv5.0 are multiplied by 0.69 .

Spatial patterns of aromatic emissions are similar across sources. After gasoline, the next highest source of aromatics is solvent usage, and Reff et al. [46] show that the spatial pattern of solvent usage is similar to gasoline, that is, occurs predominantly in urban areas. In addition, most major refineries are also in close proximity to urban areas.

\section{Adjusted CMAQv5.0 results}

Figure 1 shows the final nationwide distribution of annual average $\mathrm{PM}_{2.5}$ concentrations attributable to aromatic hydrocarbons emitted from gasoline vehicles, after applying all the adjustments to the CMAQv5.0 output described above. The nationwide average concentration based on the average predicted value for each state is approximately $0.17 \mu \mathrm{g} / \mathrm{m}^{3}$ (standard deviation $=0.06 \mu \mathrm{g} / \mathrm{m}^{3} ;$ minimum $=$ $0.03 \mu \mathrm{g} / \mathrm{m}^{3}$, maximum $=0.3 \mu \mathrm{g} / \mathrm{m}^{3}$ ) and ranges from 0.013 to greater than $0.6 \mu \mathrm{g} / \mathrm{m}^{3}$ at the county level. On a statewide basis, Table 4 shows the rank ordered concentrations by state, with Connecticut, Rhode Island, Ohio, New York,

Table 5 Premature mortality and total social cost for health impacts associated with exposure to SOA from aromatic hydrocarbons in gasoline in the lower 48 states

\begin{tabular}{|c|c|c|c|c|c|}
\hline Reference & Beta & $\begin{array}{l}\text { Premature mortality } \\
\text { (cases) }^{\mathrm{a}}\end{array}$ & $\begin{array}{l}\text { Value of mortality reduction } \\
\qquad(\$ M)^{a}\end{array}$ & $\begin{array}{l}\text { Premature mortality } \\
\text { (cases) }^{\mathbf{b}}\end{array}$ & $\begin{array}{l}\text { Value of mortality reduction } \\
\qquad(\$ M)^{\mathbf{b}}\end{array}$ \\
\hline [43] & 0.015 & $4714(2533,6897)$ & $\$ 34.9 \mathrm{~B}(\$ 18.7 \mathrm{~B}, \$ 51.0 \mathrm{~B})$ & $6330(3402,9262)$ & $\$ 46.8(\$ 25.2, \$ 68.5)$ \\
\hline$[12]$ & 0.006 & $1833(717,2951)$ & $\$ 13.6 \mathrm{~B}(\$ 5.3 \mathrm{~B}, \$ 21.8 \mathrm{~B})$ & $2462(962,3963)$ & $\$ 18.2(\$ 7.1, \$ 29.3)$ \\
\hline$[42]$ & 0.006 & $1833(1335,2332)$ & $\$ 13.6 \mathrm{~B}(\$ 9.9 \mathrm{~B}, \$ 17.2 \mathrm{~B})$ & $2462(1792,3132)$ & $\$ 18.2(\$ 13.3, \$ 23.2)$ \\
\hline [44] & 0.011 & $3816(886,6814)$ & $\$ 28.2 \mathrm{~B}(\$ 6.6 \mathrm{~B}, \$ 50.4 \mathrm{~B})$ & $5125(1189,9151)$ & $\$ 37.9(\$ 8.8, \$ 67.7)$ \\
\hline
\end{tabular}

\section{Notes:}

Value of mortality reduction $=\$ 7.4 \mathrm{M}$ per case in $2006 \$$.

Beta = percentage change in mortality for a $1 \mu \mathrm{g} / \mathrm{m}^{3}$ change in $\mathrm{PM}_{2.5}$ concentration.

(a) $=$ uniform application of the 0.69 scaling factor to account for sources of aromatic emissions.

(b) $=$ rural areas adjusted by $0.69 ; 100 \%$ of aromatic emissions in urban areas assumed to originate from gasoline. 
New Jersey and Indiana at or exceeding $0.2 \mu \mathrm{g} / \mathrm{m}^{3}$ statewide.

\section{BenMAP modeling results}

Figure 2 presents a nationwide map of predicted premature mortalities attributable to aromatic hydrocarbons in gasoline associated with the expert elicitation concentration-response function. Table 5 and Figure 3 provide a summary of predicted premature mortality and monetized estimates of social cost based on all four different concentration-response functions. Predicted premature mortalities range from nearly 1,850 to more than 4,700 cases, depending on which concentration-response function is used, which correspond with approximately $\$ 13.6 \mathrm{~B}$ to $\$ 34.9 \mathrm{~B}$ in total social costs. The $5^{\text {th }}$ and $95^{\text {th }}$ percentiles from each study are included in the parentheses, and represent the effect of uncertainty in the concentration-response functions only (e.g., there are many potential sources of uncertainty, but only those associated with the concentration-response functions are captured in BenMap). Our recommended best estimate is approximately 3,800 premature mortalities based on the mean of the expert elicitation concentration-response function. Using the central estimates from the Krewski [41] and Laden [42] studies, respectively, results in a confidence interval of 1,800 to 4,700 for a central estimate.

The results in columns 3-4 (a) in Table 5 have been adjusted by 0.69 to account for the fraction of aromatic emissions attributable to gasoline sources based on the 2005 National Emissions Inventory. However, it is possible that the fraction of aromatic emissions from gasoline could be higher in urban areas (although, as noted previously, Reff $e t$ al. [46] have shown that spatial patterns of emissions from other sources of aromatics such as solvent usage are similar to gasoline). To explore the potential impacts of this assumption, we adjust only those counties designated as rural counties [47] by 0.69 and assume that $100 \%$ of emissions in urban areas are derived from gasoline sources. The results are shown in the final two columns of Table 5 and in Figure 3. Predicted premature mortality increases to a little over 5,000, and based on the concentration-response function used, ranges from 2,400 to over 6,300.

Table 6 provides predicted premature mortalities and associated social costs for each of the four concentrationresponse functions. Figure 4 provides the results for each state, sorted from highest to lowest predicted impacts, using MetaDataViewer available from the National Toxicology Program [48] for the best estimate represented by the expert elicitation slope (the remaining results are proportional based on the results presented in Table 6; results not shown graphically). New York, with $0.21 \mu \mathrm{g} / \mathrm{m}^{3}$ of its PM2.5 attributable to aromatic SOA, shows the highest predicted impacts based on the number of exposed individuals. Ohio and Pennsylvania follow, with approximately 260 predicted premature mortalities each (based on the midpoint of the combined expert elicitation concentration-response function). The two states with the highest populations, Texas and California, are ranked eighth and tenth, respectively, for premature mortalities at approximately 170 and 130 expected cases, respectively.

\section{Discussion}

Our best estimate of potential impacts is based on the expert elicitation concentration-response function recently endorsed by a US EPA Science Advisory Board Panel together with the regression-based adjustment factors to the CMAQv5.0 predictions, resulting in 3,800 predicted premature mortalities. This compares to a recent nationwide estimate of approximately 130,000 overall premature mortalities (for 2005) associated with all $\mathrm{PM}_{2.5}$ exposures recently discussed by Fann et al. [49] and based on the Krewski et al. [41] concentrationresponse function. The results presented in Fann et al. [49] were based on CMAQv4.7 together with additional monitoring data to estimate premature mortalities attributable to exposure to $\mathrm{PM}_{2.5}$ concentrations from all sources. The incremental contribution from exposure to aromatic SOA from gasoline using the adjusted results

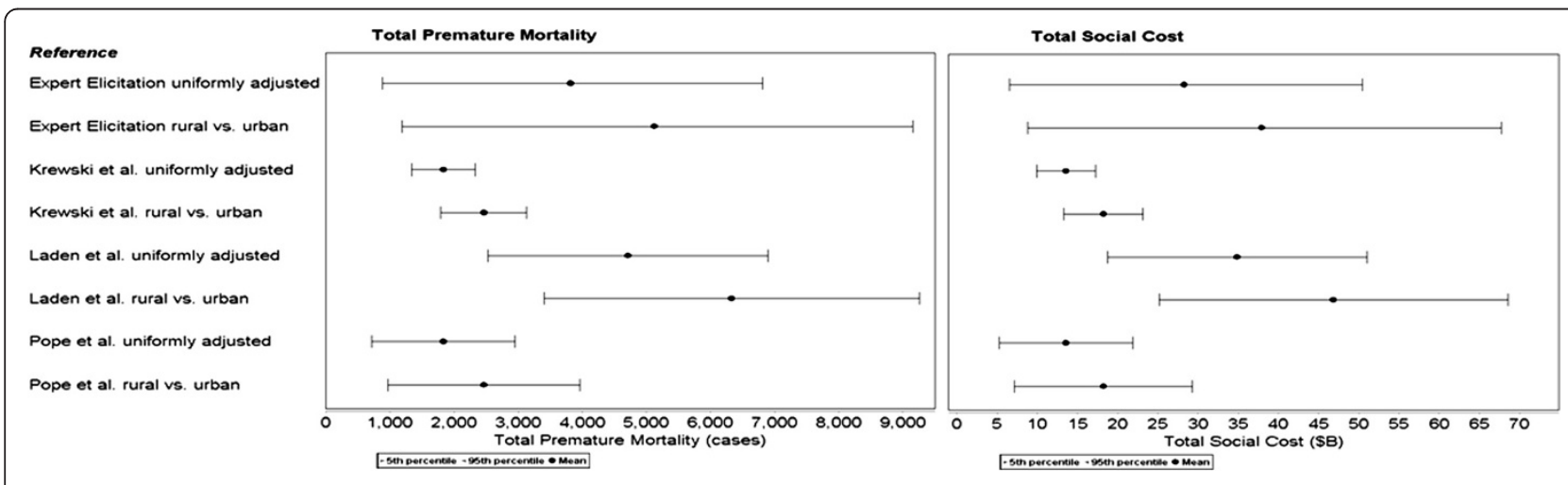

Figure 3 Incidence and total social cost associated with exposure to aromatic SOA from gasoline emissions. 
Table 6 Predicted premature mortalities and associated social costs by state (Baseline Year $=2006$ )

\begin{tabular}{|c|c|c|c|c|c|c|c|c|c|}
\hline State & $\begin{array}{l}\text { Population } \\
\text { (2006) }\end{array}$ & $\begin{array}{c}\text { Premature } \\
\text { mortality based on } \\
\text { expert elicitation } \\
\text { [43] (cases) }\end{array}$ & $\begin{array}{c}\text { Total social cost } \\
\text { based on expert } \\
\text { elicitation [43] } \\
\text { (\$M) }\end{array}$ & $\begin{array}{c}\text { Premature mortality } \\
\text { based on Krewski } \\
\text { et al. } 2009[41] \\
\text { (cases) }\end{array}$ & $\begin{array}{c}\text { Total social cost } \\
\text { based on Krewski } \\
\text { et al. } 2009(\$ M) \\
{[41]}\end{array}$ & $\begin{array}{c}\text { Premature } \\
\text { mortality based on } \\
\text { Pope et al. } 2002 \\
\text { [12] (cases) }\end{array}$ & $\begin{array}{c}\text { Total social cost } \\
\text { based on Pope } \\
\text { et al. } 2002[12] \\
\text { (\$M) }\end{array}$ & $\begin{array}{c}\text { Premature } \\
\text { mortality based on } \\
\text { Laden et al. } 2006 \\
\text { [42] (cases) }\end{array}$ & $\begin{array}{c}\text { Total social cost } \\
\text { based on Laden } \\
\text { et al. } 2006[42] \\
\text { (\$M) }\end{array}$ \\
\hline NY & $11,721,250$ & 359 & $\$ 2,659$ & 173 & $\$ 1,277$ & 173 & $\$ 1,277$ & 443 & $\$ 3,278$ \\
\hline $\mathrm{OH}$ & $7,027,236$ & 266 & $\$ 1,972$ & 128 & $\$ 947$ & 128 & $\$ 947$ & 329 & $\$ 2,433$ \\
\hline PA & $7,856,478$ & 263 & $\$ 1,943$ & 126 & $\$ 933$ & 126 & $\$ 933$ & 324 & $\$ 2,395$ \\
\hline IL & $7,826,777$ & 215 & $\$ 1,592$ & 103 & $\$ 765$ & 103 & $\$ 765$ & 266 & $\$ 1,966$ \\
\hline NJ & $6,003,804$ & 189 & $\$ 1,402$ & 91 & $\$ 673$ & 91 & $\$ 673$ & 234 & $\$ 1,730$ \\
\hline $\mathrm{FL}$ & $12,353,717$ & 173 & $\$ 1,279$ & 83 & $\$ 615$ & 83 & $\$ 615$ & 214 & $\$ 1,581$ \\
\hline MI & $6,269,921$ & 169 & $\$ 1,254$ & 81 & $\$ 602$ & 81 & $\$ 602$ & 209 & $\$ 1,549$ \\
\hline TX & $13,969,855$ & 166 & $\$ 1,231$ & 80 & $\$ 592$ & 80 & $\$ 592$ & 206 & $\$ 1,526$ \\
\hline NC & $5,523,143$ & 147 & $\$ 1,090$ & 71 & $\$ 524$ & 71 & $\$ 524$ & 182 & $\$ 1,347$ \\
\hline CA & $22,483,409$ & 133 & $\$ 988$ & 64 & $\$ 475$ & 64 & $\$ 475$ & 165 & $\$ 1,221$ \\
\hline GA & $5,572,237$ & 133 & $\$ 986$ & 64 & $\$ 474$ & 64 & $\$ 474$ & 165 & $\$ 1,221$ \\
\hline IN & $3,915,380$ & 131 & $\$ 968$ & 63 & $\$ 465$ & 63 & $\$ 465$ & 162 & $\$ 1,196$ \\
\hline MA & $4,049,798$ & 125 & $\$ 922$ & 60 & $\$ 443$ & 60 & $\$ 443$ & 153 & $\$ 1,136$ \\
\hline MO & $3,608,441$ & 106 & $\$ 787$ & 51 & $\$ 378$ & 51 & $\$ 378$ & 131 & $\$ 972$ \\
\hline VA & $4,873,441$ & 102 & $\$ 754$ & 49 & $\$ 362$ & 49 & $\$ 362$ & 126 & $\$ 931$ \\
\hline TN & $3,822,406$ & 99 & $\$ 729$ & 47 & $\$ 350$ & 47 & $\$ 350$ & 122 & $\$ 902$ \\
\hline WI & $3,619,422$ & 84 & $\$ 624$ & 40 & $\$ 300$ & 40 & $\$ 300$ & 104 & $\$ 769$ \\
\hline$C T$ & $2,253,322$ & 83 & $\$ 617$ & 40 & $\$ 296$ & 40 & $\$ 296$ & 103 & $\$ 761$ \\
\hline SC & $2,772,416$ & 82 & $\$ 605$ & 39 & $\$ 291$ & 39 & $\$ 291$ & 101 & $\$ 749$ \\
\hline$A L$ & $2,927,474$ & 81 & $\$ 599$ & 39 & $\$ 288$ & 39 & $\$ 288$ & 100 & $\$ 742$ \\
\hline KY & $2,675,868$ & 69 & $\$ 507$ & 33 & $\$ 244$ & 33 & $\$ 244$ & 85 & $\$ 628$ \\
\hline MD & $3,715,953$ & 67 & $\$ 493$ & 32 & $\$ 237$ & 32 & $\$ 237$ & 82 & $\$ 610$ \\
\hline MN & $3,314,038$ & 54 & $\$ 397$ & 26 & $\$ 191$ & 26 & $\$ 191$ & 66 & $\$ 490$ \\
\hline IA & $1,906,272$ & 48 & $\$ 353$ & 23 & $\$ 170$ & 23 & $\$ 170$ & 59 & $\$ 435$ \\
\hline MS & $1,846,049$ & 45 & $\$ 335$ & 22 & $\$ 161$ & 22 & $\$ 161$ & 56 & $\$ 416$ \\
\hline LA & $2,630,768$ & 43 & $\$ 315$ & 20 & $\$ 151$ & 20 & $\$ 151$ & 53 & $\$ 391$ \\
\hline AR & $1,803,802$ & 40 & $\$ 296$ & 19 & $\$ 142$ & 19 & $\$ 142$ & 49 & $\$ 366$ \\
\hline OK & $2,233,442$ & 38 & $\$ 283$ & 18 & $\$ 136$ & 18 & $\$ 136$ & 47 & $\$ 350$ \\
\hline KS & $1,680,031$ & 35 & $\$ 257$ & 17 & $\$ 123$ & 17 & $\$ 123$ & 43 & $\$ 317$ \\
\hline WV & $1,187,545$ & 33 & $\$ 242$ & 16 & $\$ 116$ & 16 & $\$ 116$ & 40 & $\$ 298$ \\
\hline$A Z$ & $3,911,781$ & 29 & $\$ 217$ & 14 & $\$ 104$ & 14 & $\$ 104$ & 36 & $\$ 269$ \\
\hline
\end{tabular}


Table 6 Predicted premature mortalities and associated social costs by state (Baseline Year $=2006)($ Continued)

\begin{tabular}{|c|c|c|c|c|c|c|c|c|c|}
\hline $\mathrm{NH}$ & 952,282 & 26 & $\$ 190$ & 12 & $\$ 91$ & 12 & $\$ 91$ & 32 & $\$ 234$ \\
\hline Rl & 653,356 & 25 & $\$ 187$ & 12 & $\$ 90$ & 12 & $\$ 90$ & 31 & $\$ 230$ \\
\hline ME & 904,612 & 23 & $\$ 169$ & 11 & $\$ 81$ & 11 & $\$ 81$ & 28 & $\$ 208$ \\
\hline NE & $1,058,917$ & 19 & $\$ 140$ & 9 & $\$ 67$ & 9 & $\$ 67$ & 23 & $\$ 172$ \\
\hline WA & $4,138,920$ & 18 & $\$ 135$ & 9 & $\$ 65$ & 9 & $\$ 65$ & 22 & $\$ 166$ \\
\hline NV & $1,603,777$ & 14 & $\$ 101$ & 7 & $\$ 49$ & 7 & $\$ 49$ & 17 & $\$ 125$ \\
\hline DE & 522,705 & 13 & $\$ 95$ & 6 & $\$ 45$ & 6 & $\$ 45$ & 16 & $\$ 117$ \\
\hline OR & $2,383,414$ & 12 & $\$ 90$ & 6 & $\$ 43$ & 6 & $\$ 43$ & 15 & $\$ 111$ \\
\hline VT & 436,489 & 10 & $\$ 77$ & 5 & $\$ 37$ & 5 & $\$ 37$ & 13 & $\$ 95$ \\
\hline $\mathrm{CO}$ & $2,974,597$ & 9 & $\$ 70$ & 5 & $\$ 34$ & 5 & $\$ 34$ & 12 & $\$ 87$ \\
\hline SD & 473,989 & 7 & $\$ 53$ & 3 & $\$ 25$ & 3 & $\$ 25$ & 9 & $\$ 65$ \\
\hline NM & $1,300,700$ & 6 & $\$ 47$ & 3 & $\$ 22$ & 3 & $\$ 22$ & 8 & $\$ 58$ \\
\hline UT & $1,399,252$ & 6 & $\$ 45$ & 3 & $\$ 22$ & 3 & $\$ 22$ & 8 & $\$ 56$ \\
\hline ND & 413,558 & 5 & $\$ 41$ & 3 & $\$ 19$ & 3 & $\$ 19$ & 7 & $\$ 50$ \\
\hline ID & 907,667 & 5 & $\$ 38$ & 2 & $\$ 18$ & 2 & $\$ 18$ & 6 & $\$ 47$ \\
\hline MT & 639,955 & 4 & $\$ 29$ & 2 & $\$ 14$ & 2 & $\$ 14$ & 5 & $\$ 35$ \\
\hline$D C$ & 217,088 & 4 & $\$ 28$ & 2 & $\$ 14$ & 2 & $\$ 14$ & 5 & $\$ 35$ \\
\hline WY & 347,896 & 2 & $\$ 13$ & 1 & $\$ 6$ & 1 & $\$ 6$ & 2 & $\$ 16$ \\
\hline
\end{tabular}




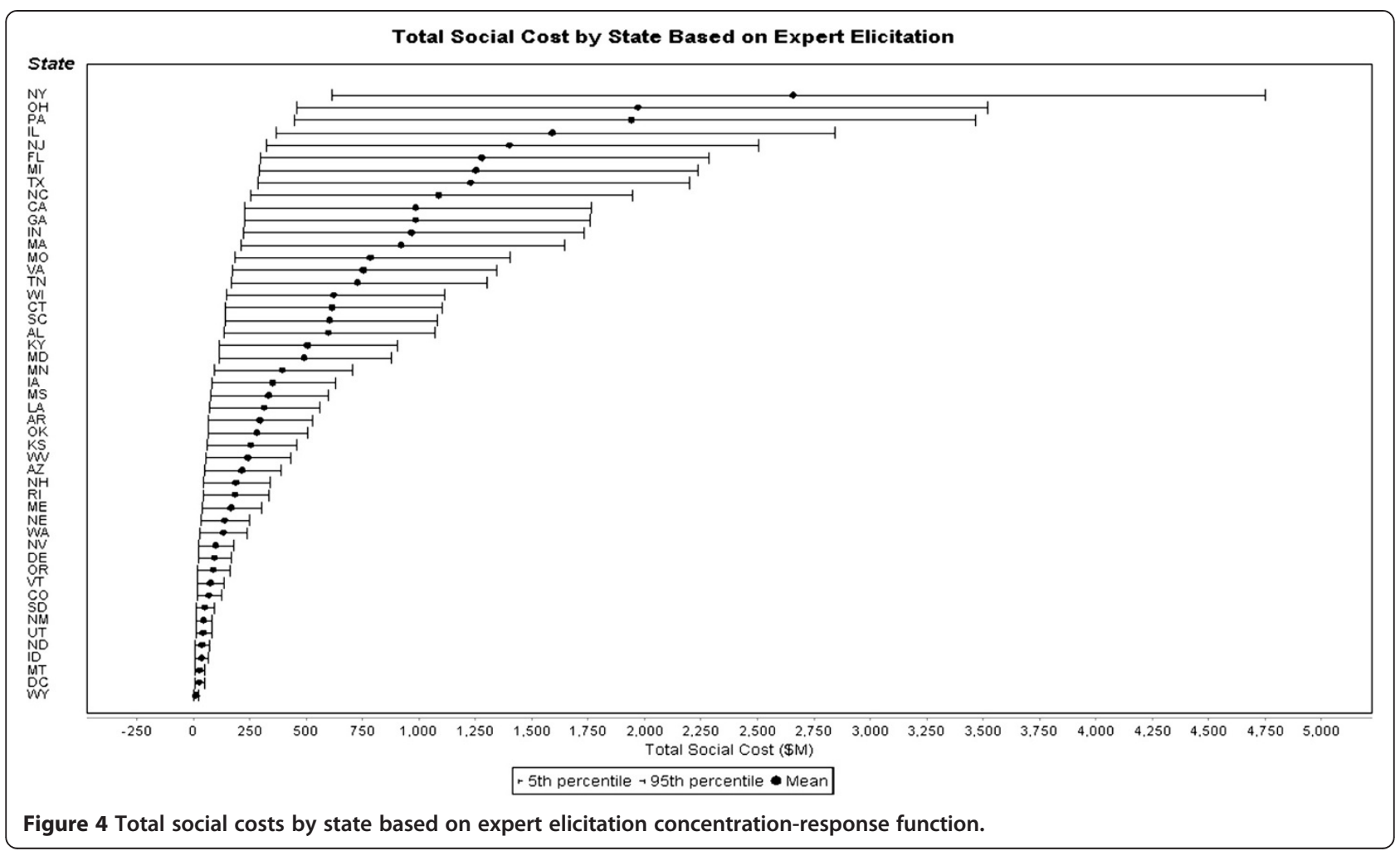

presented here and the Krewski concentration-response function represents approximately $1.4 \%$ of the total 130,000 estimated by Fann et al. [49]. While this may seem a small fraction of total PM-attributed mortality, these results are comparable to many public health measures, and with the Cross State Air Pollution Rule implementation in the next five years, are likely to constitute a higher portion of PM-related deaths in the future. Under this rule, if $\mathrm{SO}_{2}$ emissions decrease by an expected $50 \%$, sulfate will become a smaller fraction of $\mathrm{PM}_{2.5}$; therefore, other sources will become more important, particularly since SOA from aromatic hydrocarbon precursors are not expected to decrease and could represent an increasingly larger fraction of exposures.

In addition to premature mortality, which dominates monetized estimates of total social cost, exposures to SOA from aromatics in gasoline are associated with other health outcomes, including exacerbation of asthma, upper respiratory symptoms, lost work days, and hospital emergency room visits.

To put our monetized social cost (central estimate of $\$ 28.2 B$ ) in context with other analyses, a recent study evaluated the public health impacts associated with exposure to direct emissions of $\mathrm{PM}_{2.5}$ attributable to congested traffic conditions [50] and estimated a total social cost of \$31B (in 2007\$). US EPA's Heavy-Duty Highway Diesel Final Rule [51] estimates an 8,300 reduction in premature mortalities, a little more than twice the number of premature mortalities from this analysis.

While we have provided a best estimate of the public health impact of gasoline-driven aromatic SOA in PM2.5 based on current information, the exact sources of SOA remain a topic of ongoing debate. For example, a recent study in Los Angeles [52] found that gasoline emissions dominated SOA formation, accounting for nearly $90 \%$ of total aerosol formation, and the ratio of SOA to primary organic aerosol was approximately a factor of three. However, another recent study from California [53] found diesel exhaust to be responsible for $65 \%$ to $90 \%$ of vehicular-derived SOA and was 7 times more efficient at forming aerosol than gasoline exhaust. Overall, data suggest that across most areas in the U.S., SOA represents some $30 \%-40 \%$ of organic carbon concentrations [5,54-57].

Anthropogenic emissions have been shown to enhance biogenic SOA formation [58-60]. For example, SOA formation in the southeastern United States was investigated through a comparison with urban plumes in the northeast to identify biogenic versus anthropogenic precursors. The authors found that $70-80 \%$ of summertime carbon was of anthropogenic origin, and that anthropogenic precursors enhanced SOA formation from biogenic VOCs [60]. 
Photo-oxidation of aromatics has been shown to significantly contribute to anthropogenic SOA formation, but many factors contribute to variability in SOA formation that are not well understood, including spatial and chemical variability in emissions, the amount of time needed for PM formation, and varying ambient conditions at different scales [61,62]. CMAQ model performance of SOA formation has improved substantially with each version of the model, but likely doesn't capture every process, given that SOA formation depends on varying atmospheric physical and chemical conditions which are simulated at coarser scales in the CMAQ model relative to the (unknown) scales at which they occur in the environment. For example, Snyder et al. [63] found markers for mobile and other sources differed by as much as $60 \%$ within the neighborhood scale and by greater than $200 \%$ within the urban scale.

The error in tracer-based estimates of aromatic SOA formation is approximately $\pm 33 \%$ [64]; therefore, measurements are somewhat better understood than the specific processes and conditions leading to those observations. A strength of this analysis is the combination of modeling corroborated by empirical studies to provide a baseline estimate of predicted premature mortality associated with secondary organic particulate formation. Although aromatic SOA is a small component of PM2.5, our results show that exposure to secondary organic aerosol originating from aromatics in gasoline constitutes a non-trivial public health impact. Replacements for those aromatics are not risk-free themselves, and must be evaluated in a life-cycle context. As alternatives to aromatics in gasoline are contemplated, it will be important to consider the potential public health impacts associated with different transportation, fuel, and infrastructure design options (see, for example, Cook et al. [32], who developed a life-cycle assessment approach to evaluate the impacts of increased use of ethanol under several scenarios).

\section{Conclusions}

Vehicle emissions of aromatic hydrocarbons originating in gasoline contribute to secondary formation of organic particulate matter. While many uncertainties exist in the exact mechanisms involved in secondary organic aerosol formation and the scales over which these mechanisms occur, our preliminary quantitative analysis provides a baseline estimate of premature mortality in the lower 48 states. Predicted premature mortalities range from 1800 to over 4700 , demonstrating a non-trivial public health burden.

\section{Additional files}

Additional file 1: Table S1. Comparison of Observed SOA

Measurements and Unadjusted CMAQv5.0 Predictions.
Additional file 2: Table S2. US EPA'S SPECIATE Database Used to Determine the Fraction of Anthropogenic SOA from Aromatic Hydrocarbons in Gasoline.

\section{Abbreviations}

BenMAP: US EPA Benefits and Mapping Program v4.0; CB05: Carbon Bond 2005; CMAQ: Community Multiscale Air Quality modeling system;

CMAQv5.0: Community Multiscale Air Quality model version 5.0; $\mathrm{PM}_{2.5}$ : Fine particles less than $2.5 \mu \mathrm{m}$; NOx: Oxides of nitrogen; SOA: Secondary organic aerosol; VOC: Volatile organic compounds.

\section{Competing interests}

The authors declare no competing financial interests. Funding for KvS, JB, and JS was provided by the restricted gift from Boyden Gray \& Associates, PLLC to the Harvard Center for Risk Analysis. PVB participated as part of employment with the US EPA.

\section{Authors' contributions}

KvS wrote the manuscript with oversight from JS, JB conducted the BenMAP modeling using CMAQ results provided by PVB. All authors edited, read and approved the final manuscript.

\section{Acknowledgments}

Thanks go to Steven Melly for preparing Figures 1 and 2, and to Tad Kleindienst for providing observational data from the California sites. The United States Environmental Protection Agency through its Office of Research and Development collaborated in the research described here. It has been subjected to Agency review and approved for publication.

\section{Author details}

${ }^{1}$ Harvard Center for Risk Analysis, 401 Park Drive, Landmark 404J, Boston, MA 02215, USA. ${ }^{2}$ National Exposure Research Laboratory, Office of Research \& Development, U.S. Environmental Protection Agency, 109 T.W. Alexander Dr. Research Triangle Park, Durham, NC 27711, USA.

Received: 5 September 2012 Accepted: 13 February 2013 Published: 20 February 2013

\section{References}

1. Seinfeld JH, Pandis SN: Atmospheric Chemistry and Physics: From Air Pollution to Climate Change. New York: John Wiley \& Sons; 1998

2. Pandis SN, Harley RA, Cass GR, Seinfeld JH: Secondary organic aerosol formation and transport. Atmos Environ 1992, 26A:2269-2282.

3. Zhang Q, Jiminez JL, Canagaratna MR, Ulbrich IM, Ng NL, Worsnop DR, Sun Y: Understanding atmospheric organic aerosols via factor analysis of aerosol mass spectrometry: a review. Anal Bioanal Chem 2011, 401:3045-3067. doi:10.1007/s00216-011-5355-y.

4. Zhang Q, Jiminez JL, Canagaratna MR, Allan JD, Coe H, Ulbrich I, Alfarra MR, Takami A, Middlebrook AM, Sun YL, Dzepina K, Dunlea E, Docherty K, DeCarlo PF, Salcedo D, Onasch T, Jayne JT, Miyoshi T, Shimono A, Hatakeyama S, Takegawa N, Kondo Y, Schneider J, Drewnick F, Borrmann S, Weimer S, Demeriian K, Williams P, Bower K, Bahreini R, Cottrell L, Griffin RJ, Rautiainen J, Sun JY, Zhang YM, Worsnop DR: Ubiquity and dominance of oxygenated species in organic aerosols in anthropogenically-influenced Northern Hemisphere midlatitudes. Geophys Res Lett 2007, 34:L13801. doi:10.1029/2007GL029979.

5. Yu S, Bhave PV, Dennis RL, Mathur R: Seasonal and regional variations of primary and secondary organic aerosols over the continental United States: Semi-empirical estimates and model evaluation. Environ Sci Technol 2007, 41:4690-4697.

6. Castro LM, Pio CA, Harrison RM, Smith DJT: Carbonaceous aerosol in urban and rural European atmospheres: estimation of secondary organic carbon concentrations. Atmos Environ 1999, 33:2771-2781.

7. Brown SG, Herckes P, Ashbaugh L, Hannigan MP, Kreidenweis SM, Collett $J$ $\mathrm{Jr}$ : Characterization of organic aerosol present in Big Bend National Park, Texas during the Big Bend Regional Aerosol and Visibility Observational (BRAVO) Study. Atmos Environ 2002, 36:5807-5818.

8. Lim H-J, Turpin BJ: Origins of primary and secondary organic aerosols in Atlanta: results of time-resolved measurements during the Atlanta supersite experiment. Environ Sci Technol 2002, 36:4489-4496. 
9. Pope CA 3rd, Thun MJ, Namboodiri MM, Dockery DW, Evans JS, Speizer FE, Heath CW: Particulate air pollution as a predictor of mortality in a prospective study of U.S. adults. Am J Respir Crit Care Med 1995, 151:669-674.

10. Donaldson K, Li XY, MacNee W: Ultrafine (Nanometre) particle mediated lung injury. J Aerosol Sci 1998, 29:553-560.

11. Pope CA 3rd: Epidemiology of fine particulate air pollution and human health: biologic mechanisms and who's at risk? Environ Health Perspect 2000, 108:713-723.

12. Pope CA 3rd, Burnett RT, Thun MJ, Calle EE, Krewski D, Ito K, Thurston GD: Lung cancer, cardiopulmonary mortality, and long-term exposure to fine particulate air pollution. JAMA 2002, 287:1132-1141.

13. Eldering A, Cass GR: Source-oriented model for air pollutant effects on visibility. J Geophys Res 1996, 101:343-369.

14. Kleeman MJ, Eldering A, Hall JR, Cass GR: Effect of emissions control programs on visibility in southern California. Environ Sci Technol 2001, 35:4668-4674.

15. Pilinis C, Pandis S, Seinfeld JH: Sensitivity of direct climate forcing by atmospheric aerosols to aerosol size and composition. J Geophys Res 1995, 100:739-754

16. Kanakidou M, Seinfeld JH, Pandis SN, Barnes I, Dentener FJ, Facchini MC, van Dingenen R, Ervens B, Nenes A, Nielsen CJ, Swietlicki E, Putaud JP, Balkanski Y, Fuzzi S, Horth J, Moortgat GK, Winterhalter R, Myhr CEL, Tsigaridis K, Vignati E, Stephanou EG, Wilson J: Organic aerosol and global climate modelling: a review. Atmos. Chem. Phys 2004, 4:5855-6024.

17. Maria SF, Russell LM, Gilles MK, Myneni SCB: Organic aerosol growth mechanisms and their climate-forcing implications. Science 2004, 306:1921-1924.

18. Odum JR, Jungkamp TPW, Griffin RJ, Flagan RC, Seinfeld JH: The atmospheric aerosol-forming potential of whole gasoline vapor. Science 1997, 276:96-99.

19. de Gouw JA, Brock CA, Atlas EL, Bates TS, Fehsenfeld FC, Goldan PD, Holloway JS, Kuster WC, Lerner BM, Matthew BM, Middlebrook AM, Onasch TB, Peltier RE, Quinn PK, Senff CJ, Stohl A, Sullivan AP, Trainer M, Warneke C, Weber RJ, Williams EJ: Sources of particulate matter in the northeastern United States in summer: 1. Direct emissions and secondary formation of organic matter in urban plumes. J Geophys Res 2008, 113:D08301. doi:10.1029/2007JD009243.

20. Kleindienst TE, Lewandowski $M$, Offenberg JH, Edney EO, Jaoui M, Zheng M, Ding $X$, Edgerton ES: Contribution of primary and secondary sources to organic aerosol at SEARCH network sites. J Air Waste Manage Assoc 2010, 60:1388-1399.

21. Lewandowski M, Jaoui M, Offenberg JH, Kleindienst TE, Edney EO, Sheesley $\mathrm{R}$, Schauer JJ: Primary and secondary contributions to ambient PM in the midwestern United States. Environ Sci Technol 2008, 42:3303-3309.

22. Offenberg JH, Lewandowski $M$, Jaoui $M$, Kleindienst TE: Contributions of biogenic and anthropogenic hydrocarbons to secondary organic aerosol during 2006 in Research Triangle Park, NC. Aerosol Air Qual Res 2011, 11:99-108.

23. Stone EA, Zhou J, Snyder DC, Rutter AP, Mieritz M, Schauer JJ: A comparison of summertime secondary organic aerosol source contributions at contrasting urban locations. Environ Sci Technol 2009, 43:3448-3454

24. Ng NL, Kroll JH, Chan AWH, Chhabra PS, Flagan RC, Seinfeld JH: Secondary organic aerosol formation from m-xylene, toluene, and benzene. Atmos Chem Phys 2007, 7:3909-3922.

25. Kleindienst TE, Corse EW, Li W, Mclver CD, Conver TS, Edney EO, Driscoll DJ, Speer RE, Weathers WS, Tejada SB: Secondary organic aerosol formation from the irradiation of simulated automobile exhaust. J Air Waste Manage Assoc 2002, 52:259-272.

26. Docherty KS, Stone EA, Ulbrich IM, DeCarlo PF, Snyder DC, Schauer JJ, Peltier RE, Weber RJ, Murphy SM, Seinfeld JH, Grover BD, Eatough DJ, Jimenez JL: Apportionment of primary and secondary organic aerosols in Southern California during the 2005 Study of Organic Aerosols in Riverside (SOAR-1). Environ Sci Technol 2008, 42:7655-7662.

27. Carlton AG, Bhave PV, Napelenok SL, Edney EO, Sarwar G, Pinder RW Pouliot GA, Houyoux M: Model representation of secondary organic aerosol in CMAQv4.7. Environ Sci Technol 2010, 44:8553-8560.

28. Bhave PV, Pouliot GA, Zheng M: Diagnostic model evaluation for carbonaceous $\mathrm{PM}_{2.5}$ using organic markers measured in the Southeastern U.S. Environ Sci Technol 2007, 41:1577-1583.

29. Simon H, Beck L, Bhave PV, Divita F, Hsu Y, Luecken D, Mobly JD, Pouliot GA, Reff A, Sarwar G, Strum M: The development and uses of EPA's SPECIATE database. Atmospheric Pollution Research 2010, 1:196-206.
30. United States Environmental Protection Agency (USEPA): Reformulated gasoline parameters by reporting year, 2012., Available from: http://www.epa.gov/otaq/ regs/fuels/ffg/properf/rfg-params97-02.htm. Accessed March 31, 2012.

31. Gray CB, Varcoe AR: Octane, clean air, and renewable fuels: A modest step toward energy independence. Texas Review of Law \& Politics 2005, 10:9-62.

32. Cook R, Phillips S, Houyous M, Dolwick P, Mason R, Yanca C, Zawacki M, Davidson K, Michaels H, Harvey C, Somers J, Luecken D: Air quality impacts of increased use of ethanol under the United States' Energy Independence and Security Act. Atmos Env 2011, 45:7714-7724.

33. Williams BJ, Goldstein AH, Kreisberg NM, Hering SV, Worsnop DR, Ulbrich IM, Docherty KS, Jiminez JL: Major components of atmospheric organic aerosol in southern California as determined by hourly measurements of source marker compounds. Atmos Chem Phys 2010, 10:11577-11603. www.atmos-chem-phys.net/10/11577/2010/, doi:10.5194/acp-10-11577-2010.

34. Kleeman MJ, Ying Q, Lu J, Mysliwiec MJ, Griffin RJ, Chen J, Clegg S: Source apportionment of secondary organic aerosol during a severe photochemical smog episode. Atmos Environ 2007, 41:576-591.

35. Volkamer R, Jimenez JL, San Martini F, Dzepina K, Zhang Q, Salcedo D, Molina LT, Worsnop DR, Molina MJ: Secondary organic aerosol formation from anthropogenic air pollution: Rapid and higher than expected. Geophys Res Letters 2006, 33:L17811. doi:10.1029/2006GL026899.

36. Abt Associates, Inc: BenMAP: Environmental benefits and mapping analysis program. Prepared for the US EPA Office of Air Quality Planning and Standards. 2011, Available from (http://www.epa.gov/airquality/ benmap/index.html); accessed January, 2012

37. Foley KM, Roselle SJ, Appel KW, Bhave PV, Pleim JE, Otte TL, Mathur R, Sarwar G, Young JO, Gilliam RC, Nolte CG, Kelly JT, Gilliland AB, Bash JO: Incremental testing of the Community Multiscale Air Quality (CMAQ) modeling system version 4.7. Geosci Model Dev 2010, 3:205-226. www. geosci-model-dev.net/3/205/2010/.

38. Zhang $H$, Ying Q: Secondary organic aerosol formation and source apportionment in Southeast Texas. Atmos Environ 2011, 45:3217-3227

39. Hildebrandt L, Donahue NM, Pandis SN: High formation of secondary organic aerosol from the photo-oxidation of toluene. Atmos Chem Phys 2009, 9:2973-2986. www.atmos-chem-phys.net/9/2973/2009/.

40. Lewandowski M, Piletic IR, Kleindienst TE, Offenberg JG, Beaver MR, Jaoui M, Docherty KS, Edney EO: Secondary organic aerosol characterization at field sites across the United States during the spring-summer period. International Journal of Environmental Analytical Chemistry 2013, in press.

41. Krewski D, Jerrett M, Burnett RT, Ma R, Hughes E, Shi Y, Turner MC, Pope CA III, Thurston G, Calle EE, Thun MJ, Beckerman B, DeLuca P, Finkelstein N, Ito K, Moore DK, Newbold KB, Ramsay T, Ross Z, Shin H, Tempalski B: Extended follow-up and spatial analysis of the American Cancer Society study linking particulate air pollution and mortality. Res Rep Health Eff Inst 2009, 140:5-114.

42. Laden F, Schwartz J, Speizer FE, Dockery DW: Reduction in fine particulate air pollution and mortality: Extended follow-up of the Harvard Six Cities Study. Am J Respir Crit Care Med 2006, 173:667-672.

43. Industrial Economics, Inc: Expanded Expert Judgment Assessment of the Concentration-Response Relationship Between PM 25 Exposure and Mortality. Cambridge, MA: Prepared for Office of Air Quality Planning and Standards, US Environmental Protection Agency; 2006.

44. United States Environmental Protection Agency (USEPA), Advisory Council of the Clean Air Act, Health Effects Subcommittee (HES) of the Council: Review of EPA's draft health benefits of the second Section 812 Prospective Study of the Clean Air Act. 2010, (EPACOUNCIL-10-001), available at http://www.epa.gov/advisorycouncilcaa, accessed July 2012

45. United States Environmental Protection Agency (USEPA): Guidelines for preparing economic analyses.: National Center for Environmental Economics; 2010. Available from http://yosemite.epa.gov/ee/epa/eed.nsf/pages/Guidelines. html, last accessed January, 2012. See also "Frequently Asked Questions on Mortality Risk Valuation" available from: http://yosemite.epa.gov/ee/epa/eed. nsf/pages/MortalityRiskValuation.html, last accessed January, 2012.

46. Reff A, Bhave PV, Simon H, Pace TG, Pouliot GA, Mobley DM, Houyoux M: Emissions inventory of $\mathrm{PM}_{2.5}$ trace elements across the United States. Environ Sci Technol 2009, 43:5790-5796.

47. Centers for Disease Control (CDC): NCHS Urban-Rural Classification Scheme for Counties. Vital and Health Statistics 2012, Series 2, No. 154, January. U.S. Department of Health and Human Services, National Center for Health 
Statistics; 2012. Available from http://www.cdc.gov/nchs/data/series/sr_02/ sr02_154.pdf, last accessed January 2013.

48. Boyles AL, Harris SF, Rooney AA, Thayer KA: Forest Plot Viewer: a new graphing tool. Epidemiology 2011, 22:746-747.

49. Fann N, Lamson AD, Anenberg SC, Wesson K, Risley D, Hubbell BJ: Estimating the national public health burden associated with exposure to ambient $\mathrm{PM}_{2.5}$ and ozone. Risk Anal 2012, 32:81-95.

50. Levy J, Buonocore J, von Stackelberg K: Evaluation of the public health impacts of traffic congestion. Environ Health 2010, 9:65. doi:10.1186/1476-069X-9-65.

51. United States Environmental Protection Agency (USEPA): Program update. Introduction of cleaner-burning diesel fuel enables advanced pollution control for cars, trucks and buses. Office of Transportation and Air Quality; EPA420-F -06-064, October 2006. Available from http://www.epa.gov/otaq/highwaydiesel/index.htm, accessed July 2012.

52. Bahreini R, Middlebrook AM, de Gouw JA, Warneke C, Trainer M, Brock CA, Start H, Brown SS, Dube WP, Gilman JB, Hall K, Holloway JS, Kuster WC, Perring AE, Prevot ASH, Schwarz JP, Spackman JR, Szidat S, Wagner NL, Weber RJ, Zotter P, Parrish DD: Gasoline emissions dominate over diesel in formation of secondary organic aerosol mass. Geophys Res Lett 2012, 39:L06805. doi:10.1029/2011GL050718.

53. Gentner DR, Isaacman G, Worton DR, Chan AWH, Dallmann TR, Davis L, Liu S, Day DA, Russell LM, Wilson KR, Weber R, Guha A, Harley RA, Goldstein AH: Elucidating secondary organic aerosol from diesel and gasoline vehicles through detailed characterization of organic carbon emissions, PNAS 2013, early edition; 2013. www.pnas.org/cgi/doi/10.1073/pnas.1212272109.

54. Cabada JC, Pandis SN, Subramanian R, Robinson AL, Poidori A, Turpin B: Estimating the secondary organic aerosol contribution to PM2.5 using the EC tracer method. Special Issue of Aerosol Science and Technology on Findings from the Fine Particulate Matter Supersites Program. Aerosol Sci Tech 2004, 38:140-155.

55. Pachon JE, Balachandran S, Hu Y, Weber RJ, Mulholland JA, Russell AG: Comparison of SOC estimates and uncertainties from aerosol chemical composition and gas phase data in Atlanta. Atmos Env 2010, 44:3907-3914.

56. Zhang Y, Sheesley R, Schauer JJ, Lewandowski M, Jaoui M, Offenberg JH, Kleindienst TE, Edney EO: Source apportionment of primary and secondary organic aerosols using positive matrix factorization (PMF) of molecular markers. Atmos Env 2009, 43:5567-5574.

57. Chen J, Ying Q, Kleeman MJ: Source apportionment of wintertime secondary organic aerosol during the California regional $\mathrm{PM}_{10} / \mathrm{PM}_{2.5}$ air quality study. Atmos Environ 2010, 44:1331-1340.

58. Carlton AG, Pinder RW, Bhave PV, Pouliot GA: To what extent can biogenic SOA be controlled? Environ Sci Technol 2010, 44:3376-3380.

59. Hoyle CR, Boy M, Donahue NM, Fry JL, Glasius M, Guenther A, Hallar AG, Huff Hartz K, Petters MD, Pet T, Rosenoern T, Sullivan AP: A review of the anthropogenic influence on biogenic secondary organic aerosol. Atmos Chem Phys 2011, 11:321-343. www.atmos-chem-phys.net/11/321/2011/ doi:10.5194/acp-11-321-2011.

60. Weber RJ, Sullivan AP, Peltier RE, Russell A, de Zheng BM, Gouw J, Warneke C, Brock C, Holloway JS, Atlas EL, Edgerton E: A study of secondary organic aerosol formation in the anthropogenic-influenced southeastern United States. J Geophys Res 2007, 112:D13302. doi:10.1029/2007JD008408.

61. Rickard AR, Wyche KP, Metzger A, Monks PS, Ellis AM, Dommenc U, Baltensperger U, Jenkin ME, Pilling MJ: Gas phase precursors to anthropogenic secondary organic aerosol: Using the master chemical mechanism to probe detailed observations of 1,3,5 trimethylbenzene photo-oxidation. Atmos Environ 2010, 44:5423-5433. doi:10.1016/j. atmosenv.2009.09.043.
62. Lane TE, Donahue NM, Pandis SN: Simulating secondary organic aerosol formation using the volatility basis-set approach in a chemical transport model. Atmos Environ 2008, 42:7439-7451. doi:10.1016/j.atmosenv.2008.06.026.

63. Snyder DC, Rutter AP, Worley C, Olson M, Plourde A, Bader RC, Dallman T, Schauer JJ: Spatial variability of carbonaceous aerosols and associated source tracers in two cites in the Midwestern United States. Atmos Environ 2010, 44:1597-1608.

64. Kleindienst TE, Jaoui M, Lewandowski M, Offenberg JH, Lewis CW, Bhave PV, Edney EO: Estimates of the contributions of biogenic and anthropogenic hydrocarbons to secondary organic aerosol at a southeastern US location. Atmos Environ 2007, 41:8288-8300. doi:10.1016/j.atmosenv.2007.06.045.

\section{doi:10.1186/1476-069X-12-19}

Cite this article as: von Stackelberg et al:: Public health impacts of secondary particulate formation from aromatic hydrocarbons in gasoline. Environmental Health 2013 12:19.

\section{Submit your next manuscript to BioMed Central and take full advantage of:}

- Convenient online submission

- Thorough peer review

- No space constraints or color figure charges

- Immediate publication on acceptance

- Inclusion in PubMed, CAS, Scopus and Google Scholar

- Research which is freely available for redistribution

Submit your manuscript at www.biomedcentral.com/submit
() Biomed Central 